\title{
Origin of Asexual Reproduction in Hydra
}

\author{
Stanley Shostak* \\ Department of Biological Sciences, University of Pittsburgh, USA
}

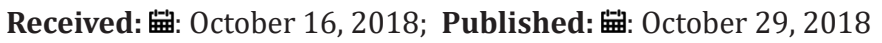

*Corresponding author: Stanley Shostak, Department of Biological Sciences, University of Pittsburgh, USA

\section{Introduction}

Hydra's buds develop through the integrated activity of two different types of cells:

a) Epithelial (aka epithelial-muscular) cells forming the didermic body wall (with extension into tentacles, hypostome, and foot) and

b) Interstitial cells (aka amoeboid or basal cells) differentiating as cnidocytes (aka nematocytes, the cells that make cnidocysts, aka nematocysts), nerve, gland, and sex cells [1-3].

Over the years, I consolidated some ideas and data into a theory about how these different kinds of cells came to cooperate in budding [4-8]. I proposed that early in the Neoproterozoic Era a primitive two layered epithelial mat (resembling contemporary Placozoa [9-10]), was infected by amoeboid cells already equipped with an extrusion apparatus. The epithelia's attempt to reject the foreign cells failed but a symbiogenic relationship evolved and the duel system found a selective advantage in modified ejection. Ultimately, a mechanism for removing excess amoeboid cells was adapted for the production of buds. The adaptation hinged on three conditions:

i. Amoeboid cells equipped with an extrusion apparatus were the ancestors of hydra's interstitial cells.

ii. Hydra routinely produced excess cells that moved toward and accumulate in the budding region.

iii. Excess cells form discrete modules that erupt as buds and are then "ejected."

a) Amoeboid cells equipped with an extrusion apparatus were the ancestors of hydra's interstitial cells. I am hardly the first to point to the presence of stinging apparatuses in protozoans and to similarities between protozoan "cnidocysts" and cnidarian cnidocysts: the "peduncle," "rhizoid," and "perforator" cnidocysts of dinoflagellates [11-14], the trichocysts of trypanosomes [15], zooflagellates [16] and mastigophorans [17], the "apicoplasts" (apical complexes) of "Sporozoa," the "polaroplast," of microsporidians [18], and the "polar capsules" of myxosporidians [19-25]. Jiři Lom, the distinguished Czech protozoologist and parasitologist, suggested that these "homologies [were] perhaps too close to be considered only a convergency phenomenon" [26], and Pierre Tardent, the renowned Swiss coelenterologist commented "The wheel didn't have to reinvent itself" [27], i.e., cnidrians didn't have to invent cnidocysts. It is a small step to extend Lynn Margulis' hypothesis of endosymbiosis [28] from mitochondria and chloroplasts to cnidocysts. Ancient eukaryotic amoeba could have been infected by monerans (presumably bacteria) already equipped with an eversion apparatus. The "guest" would then introduce genes to the "host" through unilateral horizontal gene transfer, and a permanent extrusion apparatus (a cnidocyst) would have evolved in the amoeba. What followed was a different sort of symbiosis -symbiogeny - the merging and mutual evolution of eukaryotes [5-6]. In the case of cnidarians, at some point in the evolution of multicellular eukaryotic life, probably prior to the Vendian Period 700 million years ago, an amoeboid protoctistan (to use Margulis' term [29], aka protozoan) already equipped with an extrusion apparatus gained access to a primitive didermic metazoan mat either by invading or being ingested. I suggest that, at the time, mechanisms for isolating different forms of metazoan life were not as restrictive as they became since and the efforts of the epithelia to reject the amoeba were feeble.

Thus, the protoctistan wound up sequestered in the primitive epithelium, and the two entered a symbiogenic relationship in which each symbiont evolved to mutual advantage. Inevitably, cooperation gave rise to the rudiments of the phylum Cnidaria. "Are cnidarians composite metazoans... metazoan chimeras" [30]? Did what begin as a protoctistan equipped with a cnidocyst whether trespasser, guest, foreigner, invader, colonizer, or ingested prey - become Cnidaria's interstitial cells, while the epithelial mat -host, victim, or predator -evolved into the cnidarian epithelia? 
Had that happened, interactions between the two could have led to the further evolution of nerve and gland cells from amoeboid descendants, while the cellular mat could have evolved into the cnidarian body wall's epidermis and gastrodermis, tentacles with epithelial battery cells, hypostome, peduncle, and adhesive foot.

b) Hydra routinely produces excess cells that move toward and accumulate in the budding region. One of Hydra's attraction to biologists is that under optimal laboratory conditions, hydra cultures expand exponentially. The cell populations also expand exponentially [31-34]. Since the density of hydra's cell populations is constant, except for transient increases in the budding region, hydras would seem to produce and get rid of excess cells. Rather than treating these cells as waste, however, symbiogeny capitalized on them by adapting them for asexual reproduction through budding. The movement of cells toward the budding region is well documented. Richard Campbell [31-35] calculated, that in $H$. littoralis, under optimal laboratory conditions, $85-86 \%$ of hydra's structural cells produced throughout the body cylinder (gastric, budding, and upper peduncle regions) migrate to the budding region. Similarly, in $H$. viridis, about 800 of a thousand parental gastrodermal [digestive] cells move to the budding region per day [34].

Likewise, interstitial cells and their differentiation intermediates make up more than half of all the cells in the adult animal moving to the budding region [36]. The remainder of a hydra's daily cellular production is lost at the animal's extremities, tentacles and foot. All the excess cells dedicated to budding are produced along the length of hydra's body wall [31-37] in speciesspecific patterns of cell division. Paul Brien discovered "La zone de croissance sous hypostomiale" (Brien's sub-hypostomal growth zone) in Hydra fusca [38], and Allison Burnett extended Brien's growth zone in $H$. viridis and H. pseudoligactis (H. canadensis) to the gastric and budding regions [39] where a high frequency of mitotic figures is also found. Campbell showed that in H. littoralis, a distal zone of elevated mitotic activity appears among epidermal epitheliomuscular cells (a.k.a. "Ectodermal epithelial cells") and gastrodermal gland cells (a.k.a. "Endodermal gland cells"), but cell proliferation peaks in the budding region for interstitial cells ("Ectodermal interstitial cells," a.k.a. basal cells, amoeboid cells) and gastrodermal epitheliomuscular cells (a.k.a. "Endodermal epithelial cells") [33, 35, 40-42].

Measured in mitotic figures and in the incorporation of tritiated thymidine, the epidermis supports a higher rate of cell division than the gastrodermis [33] and labeled epidermal epitheliomuscular cells move toward the budding region faster than gastrodermal digestive cells [32-34]. Whatever the cell type, and wherever along the body column cells are produced (i.e., both above and below the budding region) they converge on the budding region [33-35,40-43]. The mesoglea situated between the epidermis and gastrodermis is a substratum for cell movement rather than a glue holding the two epithelial layers together. Epithelial-muscle cells, with longitudinal muscle extensions seem to actively crawl on the mesoglea with the help of their muscle processes [44] and are seen to migrate over experimentally denuded mesoglea [45]. In contrast, the gastrodermal epithelial-muscle (digestive) cells with circular muscle extensions seem to become compressed and crowded into the budding region [46].

c) Excess cells form discrete modules that erupt as buds and are then "ejected." Neither the budding region nor buds are distinctive fountains of proliferating cells, meristems, or blastemata. Likewise, in $H$. viridis, the frequencies of mitotic figures in early buds lacking tentacles (stage I) and buds with tentacle rudiments (stage II) "could not be distinguished." Given the absence of mitotic figures in the hypostome, the "number of mitotic figures on the bud proper at the later stage" (stage III) is below that on the parent [32]. Moreover, cell divisions proceed at the same rate in freshly detached buds, during the initial growth period, and in budding animals [32,34,47-51]. The distinguishing characteristic of the budding region is the local production of new mesogleal components [52-54]. Indeed, "[a]t sites of tissue evagination... the mesoglea was dramatically remodeled and epithelial cells moved relative to the mesoglea" [43].

Thus, "no loss of ECM [i.e., extracellular material of the mesoglea] occurs before the time of bud emergence. Rather, the ECM is continuous at the sites of bud formation and what occurs is simply an increase in the expression of... [mesogleal components] as evagination of the bud progresses.... Before evagination of the bud occurs... upregulation of at least... [one mesogleal components] has already occurred. High expression of both basement membrane and interstitial matrix components occurs throughout all stages of bud formation" [54].

Hydra's excess cells funneled into the budding region form discrete bud modules that break with parental symmetry, jut outward, form a hypostome, tentacles, body cylinder, and feet, and ultimately detach as buds [8, 30-35]. In transgenic H. vulgaris [43] and grafted $H$. viridis [55], cells are literally seen moving out onto buds. "[C]ells located near the evaginating centre will end up in the oral/distal part of the bud; those located more distantly will move to a more aboral/proximal part of the bud" [46]. The further "[e] longation of the early bud is driven by recruitment of epithelial tissue from the mother polyp into the newly forming protrusion" [46]. Interstitial cells may play a special role in bud modules, since hydras partially or fully (?) deprived of interstitial cells, so-called "epithelial animals," have difficulty budding. Hydras' interstitial cell population is reduced or eliminated in a variety of ways: treatment with colchicine, nitrogen mustard (NM), hydroxyurea, urethane, and lowered temperature [56-62]. Treated hydras suffer addition losses beyond interstitial cells: Specialized nerve and gland cells disappear, and the hydras neither move, capture prey, or ingest them. They do not restore the missing cells either. If they survive the initial treatment, "epithelial animals" frequently die from bacterial infections of slowly healing wounds inadvertently inflicted during forced feeding and evacuation. Surviving hydras (one in twenty) may enlarge, especially in their peduncle, and add thin supernumerary tentacles [56].

Photographs of "epithelial animals" show bloated hydras with stubby tentacles [56,58]. Like starved animals [63-66], "epithelial 
animals" bud initially, and they are capable of regenerating thin tentacles lacking cnidocysts, but without feeding the animals shrink in size [58]. Interstitial cell populations can be restored, however, in "epithelial animals" [67] and in clones of reaggregated cells from NM-treated hydras [68-70] through grafting with normal tissue. Along with the missing interstitial cells and cell linages [70], including eggs [71] and sperm [72], the hydras re-acquire normal morphology and behavior.

\section{Discussion}

Under optimal laboratory conditions, hydras reach an equilibrium (a steady state) at which body size is constant and the rate of cell production is balanced by the rate of cell loss through budding (everything else being equal such as cell loss on tentacles and foot). At equilibrium, excess cells move to the budding region, join bud modules, and move off the parental body column into developing buds [30-41]. In contrast, starved hydras and "epithelial animals," deprived of interstitial cells and their products only produce buds initially while shrinking [64-66] and then cease budding. A residue of bud modules would seem to be fully determined at the initiation of starvation and interstitial cell destruction (albeit foot cells involved in detachment may be defective in "epithelial animals"). But starved animals resume budding when feeding is resumed, and "epithelial animals" resume budding when interstitial cells are reintroduced [67-72].

The failure of starved animals to continue budding is easily explained by the failure of these animals to fill bud modules, but the absence of budding in "epithelial animals" (deprived of interstitial cells and their products) suggests that epithelia alone are incapable of rejecting cells in buds. Thus, hydra's epithelia need a dose of interstitial cells to reject cells in buds. Interstitial cells would seem to provide an essential component of bud modules required for cell rejection or a trigger for the eruption of a bud from its module. The premise that budding evolved from a primitive epithelia's attempt to reject foreign amoeboid cells is consistent with these observations. Symbiogeny's constructive and creative roles in evolution might have modified cellular rejection into budding given budding's selective advantage [3-8]. "Natural selection... is not [after all] the only force governing evolution, nor had Darwin ever suggested that it was" [75]. The evolution of eukaryotes following the capture of mitochondria and chloroplasts certainly justifies Lynn Margulis' claims for the creative consequences of endosymbiosis [28-29]. Likewise, the creative power of symbiogeny, is implicit in the comparison between pond amoeba and blood-borne magakaryocytes. The evolution of budding from the rejection of amoeboid cells by a primordial epithelial mat at the beginning of hydra's evolutionary history would seem another example of how creativity is captured by natural selection [5,73-74].

\section{References}

1. Shostak S (2018) Is Hydra an alarm clock? Biomedical Journal of Scientific \& Technical Research.

2. Shostak S (2018) Hydra's Clockwork Budding. Euro Evo Devo 2018, 26 29 June 20018 | NUIG, Galway, Ireland
3. Shostak S (2018) Symbiogeny and the Evolution of Tissues. A SMBE and ASN Sponsored Regional Meeting in Pittsburgh.

4. Shostak S (1993) A symbiogenetic theory for the origins of cnidocysts in Cnidaria. Biosystems 29(1): 49-58.

5. Shostak S (2015) Symbiogeny and the Evolution of Tissues: The Hypothesis. Biol syst Open Access 4: 127.

6. Shostak S (2015) How Cnidaria got its cnidocysts. Biol Syst Open Access 4: 139.

7. Shostak S, M Landy (2016) Symbiogeny and the rhizomatic. Trends Devel Biol 9: 17-26.

8. Shostak S (2017) Hydra's complexity: Budding and cancer. Trends Devel Biol 10: 31-39.

9. Grell KG, A Ruthmann (1991) Placozoa. In: Microscopic Anatomy of Invertebrates FW Harrison and JA Westfall (Eds.). Wiley-Liss, New York, USA, pp. 13-27.

10. Christen R, A Ratto, A Baroin, R Perasso, KB Grell et al. (1991) Origin of metazoans: A phylogeny deduced from sequences of the $28 \mathrm{~S}$ ribosomal RNA. EMBO J 10(3): 499-503.

11. Chatton E (1938) Recherches taxonomiques et cytologiqques sur les Dinoflagellés libres du genre Polykrikos, Butschli leurs cnidocystes et la cnidogénèse. In: Traites et Travaux scientifiques (1906-1937) Imprimerie E Sottano, Sète, pp. 63-75.

12. Hovasse R (1951) Contribution a l'etude de la cnidogésèse chez les péridiniens. I Cnidogénèse cyclique chez Polykrikos schwartzi Butschli. Archiv Zoologische Experimentale Genetik 87: 299-344.

13. Lom J, J Vávra (1961) A proposal to the classification within the subphylum cnidospora. System Biol 11(4): 172-175.

14. Westfall JA, PC Bradbury, JW Townsend (1983) Ultrastructure of the dinoflagellate Polykrikos. I. Development of the nematocyst-taeniocyst complex and morphology of the site for extrusion. J Cell Sci 63: 245-261.

15. Gibson SC, J Lom, H Pecková, VR Ferris, PB Hamilton (2005) Phylogenetic analysis of freshwater fish trypanosomes from Europe using ssu rRNA gene sequences and random amplification of polymorphic DNA. Parasitol 130(4): 405-412.

16. How AT, D Bass, K Vickerman, EE Chao, T Cavalier Smith (2009) Phylogeny, taxonomy, and astounding genetic diversity of glissomonadida ord. nov, the dominant gliding zooflagellates in soil [Protozoa: Cercozoa]. Protist $160(2): 159-189$.

17. Vinkerman K, G Brugerolle, JP Mignot (1991) Mastigophora, in Microscopic Anatomy of Invertebrates vol. 1 Protozoa, FW Harrison \& JA Westfall (Eds.). NY: Wiley-Liss, New York, USA, pp. 13-159.

18. Perkins FO (1991) "Sporozoa": Apicomplexa, Microsporidia, Haplosporidia, Paramyxea, Myxosporidia and Actinosporida In: Microscopic Anatomy of Invertebrates, FW Harrison \& JA Westfall (Eds.). New York, NY: Wiley-Liss, pp. 261-331.

19. Wolf K, ME Markiw (1984) Biology contravenes taxonomy in the Myxozoa: New discoveries show alternation of invertebrate and vertebrate hosts. Science 225(4669): 1449-1452.

20. Nesnidal MP, M Helmkampf, I Bruchhaus, M El Matbouli, B Hausdorf (2013) Agent of Whirling Disease Meets Orphan Worm: Phylogenomic Analyses Firmly Place Myxozoa in Cnidaria. PLoS ONE 8: e54576.

21. Schlegel M, J Lom, A Stechmann, D Bernhard, D Leipe, et al. (1996) Phylogenetic analysis of complete small subunit ribosomal RNA coding region of Myxidium lieberkuehni: Evidence that Myxozoa are Metazoa and related to the Bilateria. Arch Protistenkd 147(1): 1-9.

22. Holland JW, B Okamura, H Hartikainen, CJ Secombes (2011) A novel minicollagen gene links cnidarians and myxozoans. Proc R Soc B 278(1705): 546-553. 
23. Shpirer E, ES Chang, A Diamant, N Rubinstein, P Cartwright, et al. (2014) Diversity and evolution of myxozoan minicollagens and nematogalectins. BioMedical Conference Evol Biol 14: 205.

24. Raikova E (2005) Cytomorphological characteristics of Polypodium hydriforme and problems of myxozoan and cnidarian phylogeny. Tsitologiia 47(10): 933-999.

25. Evans NM, MT Holder, MS Barbeitos, B Okamura, P Cartwright (2010) The phylogenetic position of myxozoa: exploring conflicting signals in phylogenomic and ribosomal datasets. Mol Biol Evol 27(12): 2733-2746.

26. Lom J (1990) Phylum Myxozoa In: Handbook of Protoctista, L Margulis, JO Corliss, M Melkonian, and DJ Chapman (Eds.). Jones and Bartlett. Boston, pp. 36-52.

27. Tardent P (1990) Correspondence. Personal communication.

28. Margulis L (1970) Origin of Eukaryotic Cells: Evidence and Research Implications for a Theory of the Origin and Evolution of Microbial, Plant, and Animal Cells on the Precambrian Earth. New Haven, CN: Yale University Press.

29. Margulis L (1990) Introduction pp, xi-xxiii in Lynn Margulis et al. (Eds.) Handbook of Protoctista. Boston, MA: Jones \& Bartlett.

30. Shostak S (1993) Cnidaria In: KG \& RG Adiyodi (Eds.). Reproductive Biology of Invertebrates Vol. VI, Part A: Asexual Propagation and Reproductive Strategies. New Delhi: Oxford \& IBH Publishing, pp. 45105.

31. Campbell RD (1965) Growth and tissue renewal patterns in Hydra littoralis. Thesis, The Rockefeller Institute.

32. Shostak S, NG Patel, AL Burnett (1965) The role of mesoglea in mass cell movement in Hydra. Devel Biol 12(3): 434-450.

33. Campbell RD (1967) Tissue dynamics of steady state growth in Hydra littoralis. I Patterns of cell division. Devel Biol 15(5): 487-502.

34. Shostak S (1968) Growth in Hydra viridis. J Exp Zool 169(4): 431-446.

35. Campbell RD (1967) Tissue dynamics of steady state growth in Hydra littoralis. II Patterns of tissue movement. J Morphol 121(1): 19-28.

36. Bode H (1988) Control of nematocyte differentiation in Hydra In: David A Hessinger \& Howard M Lenhoff, The Biology of Nematocysts. NY: Academic Press, New York, USA, pp. 209-232.

37. Clarkson SG, L Wolpert (1967) Bud morphogenesis in Hydra. Nature 214: 780-783.

38. Brien P, M Renier Decoen (1949). La croissance, la blastogénèse, l’ovogénèse chez Hydra fusca (Pakkas). Bull Biol Fracnce et Belg 83(4): 293-396.

39. Burnett AL (1961) The growth process in Hydra. J Exp Zool 146(1): 21 84.

40. Campbell RD (1974) Cell movement in Hydra. Amer Zool 14: 523-535.

41. Campbell RD (1967c) Tissue dynamics of steady state growth in Hydra littoralis. III Behavior of specific cell types during tissue movement. J Exp Zool 164(3): 379-392.

42. Otto JJ, RD Campbell (1977) Tissue economics of hydra: regulation of cell cycle, animal size and development by controlled feeding rates. J Cell Sci 28: 117-132.

43. Aufschnaiter R, EA Zamir, CD Little, S Özbek, S Münder, et al. (2011) In vivo imaging of basement membrane movement: ECM patterning shapes Hydra polyps. J Cell Sci 124(23): 427-438.

44. Campbell RD (1980) The role of muscle processes in Hydra morphogenesis" pp 421-428 in P \& R Tardent (eds.) Developmental and Cellular Biology of Coelenterates. Amsterdam: Elsevier/North-Holland Biomedical Press.

45. Shostak S, M Globus (1966) Migration of epithelia-muscular cells in Hydra. Nature 210: 218-219.
46. Aufschnaiter R, R Wedlich-Söldner, X Zhang, B Hobmayer (2017) Apical and basal epitheliomuscular F-actin dynamics during Hydar bud evagination. Biology Open 6(8): 1137-1148.

47. Park HD, AB Ortmeyer (1973) Growth and differentiation in Hydra: II. The effect of temperature on budding in Hydra littoralis. J Exp Zool 179: 283-88.

48. Bisbee JW (1973) Size determination in Hydra: The roles of growth and budding. J Exp Morphol 30(1): 1-19.

49. Shostak S (1974) The complexity of Hydra: Homeostasis, morphogenesis, control and integration. Quart Rev Biol 49(4): 287-310.

50. Shostak S (1979) Digestive cell and tentacle number in freshly detached buds of Hydra viridis. Internat J Invert Repro 1(3): 167-178.

51. Shostak S (1980) Can Hydra count? In: P \& R Tardent (Eds.). Development and Cellular Biology of Coelenterates. Amsterdam: Elsevier/NorthHolland Biomedical Press. pp. 231-236.

52. Shostak S, DR Kankel (1967) Morphogenetic movements during budding in Hydra. Devel Biol 15(5): 451-463.

53. Burnett AL, RE Hausman (1969) Mesoglea of Hydra. 2. Possible role in morphogenesis. J Exp Zool 171(1): 15-24.

54. Shimizu H, X Zhang, J Zhang, A Leontovich, K Fei, et al. (2002) Epithelial morphogenesis in hydra requires de novo expression of extracellular matrix components and matrix metalloproteinases. Develop 129(6): 1521-1532.

55. Shostak S (1967) Bud movement in Hydra. Science 155(3769): 15671568.

56. Campbell RD (1976) Elimination by Hydra interstitial and nerve cells by means of colchicine. J Cell Sci 21(1): 1-13.

57. David CN, S Murphy (1977) Characterization of interstitial stem cells in hydra by cloning. Devel Biol 58(2): 372-383.

58. Marcum BA, RD Campbell (1982) Eliminating all nonepithelial cells using colchicine. In: Howard M Lenhoff (Eds.). Hydra: Research Methods. New York, USA, pp. 281-290.

59. Bode HR (1982) Reducing populations of interstitial cells and nematoblasts with hydroxyurea. In: Howard M Lenhoff (Eds.). Hydra: Research Methods. New York, USA, pp. 291-294.

60. Novak P (1982) Preparing Hydra viridis with nerve cells and no interstitial cells, or with neither of these cell types. In: Howard M Lenhoff (Eds.). Hydra: Research Methods. New York, USA, pp. 295-297.

61. David CN (1982) Eliminating interstitial cells with nitrogen mustard. In: Howard M Lenhoff (Eds.). Hydra: Research Methods. New York, USA, pp. 299-302.

62. Fradkin CM (1982) Altering cell population levels by gamma irradiation. In: Howard M Lenhoff (Eds.). Hydra: Research Methods. New York, USA, pp. 303-304.

63. Brien P, M Renier Decoen (1955) La signification des cellules interstitielles des Hydres d'eau douce et le problème dela reserve embryonnaire. Bull Biol Fr Belg 89: 258-325.

64. Diel FA, AL Burnett (1965) The role of interstitial cells in the maintenance of Hydra II Budding. J Exp Zool. 158: 283-298.

65. Webster G, S Hamilton (1972) Budding in Hydra: The role of cell multiplication and cell movement in bud initiation. J Embrol exp Morphol 27(2): 301-316.

66. Bode HR, KM Flick, GS Smith (1976) Regulation of interstitial cell differentiation in Hydra attenuata. I. Homeostatic control of interstitial cell population size. J Cell Sci 20: 29-46.

67. Sproull F, David CN (1979) Stem cell growth and differentiation in Hydra attenuata. I. Regulation of the self-renewal probability in multiclone aggregates. J Cell Sci 38: 155-169. 
68. Sproull F, David CN (1979) Stem cell growth and differentiation in Hydra attenuata. II. Regulation of nerve and nematocyte differentiation in multiclone aggregates. J Cell Sci 38: 171-179.

69. David CN (2012) Interstitial stem cells in Hydra: multipotency and decision-making. Int J Devel Biol 56(6-8): 489-497.

70. Littefield CL (1991) Cell lineages in Hydra: isolation and characterization of an interstitial stem cell restricted to egg production in Hydra oligactis. Devel Biol 143(2): 378-388.

71. Littlefield CL (1985) Germ cells in Hydra oligactis males. I. Isolation of a subpopulation of interstitial cells that is developmentally restricted to sperm production. Devel Biol 112(1): 185-193.

\section{ISSN: 2574-1241}

DOI: $10.26717 /$ BJSTR.2018.10.001966

Stanley Shostak. Biomed J Sci \& Tech Res

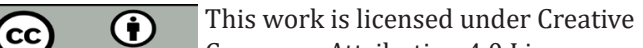

Submission Link: https://biomedres.us/submit-manuscript.php
72. Shostak S (1993) A symbiogenetic theory for the origins of cnidocysts in Cnidaria. Biosystems 29(1): 49-58.

73. Siddiqui R, NA Khan (2012) Acanthoamoeba is an evolutionary ancestor of macrophages: a myth or reality? Exp Parasitol 130(2): 95-97.

74. Shostak S, Kolluri V (1995) Symbiogenetic origins of cnidarian cnidocysts. Symbiosis 19(1): 1-29.

75. Ehrenreich B (2018) Natural Causes: An Epidemic of Wellness, the Certainty of Dying, and Killing Ourselves to Live Longer. New York, NY: Hatchette Book Group.

$\begin{array}{ll}\text { BIOMEDICAL } & \text { Assets of Publishing with us } \\ \text { RESEARCHES } & \text { - Global archiving of articles } \\ \text { - Immediate, unrestricted online access }\end{array}$

